No. Daftar FPEB: 026/UN40.F7.S1/PK.05.01/2021

ANALISIS KINERJA KEUANGAN BANK UMUM SYARIAH DI INDONESIA BERDASARKAN ISLAMICITY PERFORMANCE INDEX

PERIODE 2015-2019

\title{
SKRIPSI
}

Diajukan untuk Memenuhi Sebagian Syarat Memperoleh Gelar Sarjana Ekonomi pada Program Studi Ilmu Ekonomi dan Keuangan Islam

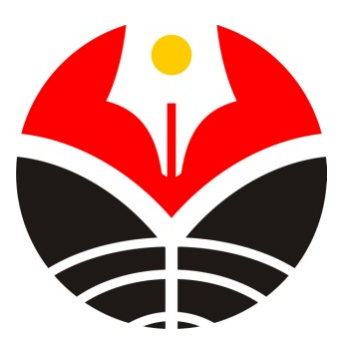

Oleh:

Fakhry Hafiyyan Kurniawan

1705048

PROGRAM STUDI ILMU EKONOMI DAN KEUANGAN ISLAM

FAKULTAS PENDIDIKAN EKONOMI DAN BISNIS

UNIVERSITAS PENDIDIKAN INDONESIA

2021

Fakhry Hafiyyan Kurniawan, 2021

ANALISIS KINERJA KEUANGAN BANK UMUM SYARIAH DI INDONESIA BERDASARKAN ISLAMICITY

PERFORMANCE INDEX PERIODE 2015-2019

Universitas Pendidikan Indonesia | repository.upi.edu | perpustakaan.upi.edu 


\section{ANALISIS KINERJA KEUANGAN BANK UMUM SYARIAH DI INDONESIA BERDASARKAN ISLAMICITY PERFORMANCE INDEX PERIODE 2015-2019}

Oleh:

Fakhry Hafiyyan Kurniawan

Sebuah Skripsi yang Diajukan untuk Memenuhi Salah Satu Syarat Memperoleh Gelar Sarjana Ekonomi (S.E) pada Program Studi Ilmu Ekonomi dan Keuangan Islam

(C) Fakhry Hafiyyan Kurniawan 2021

Universitas Pendidikan Indonesia

Januari 2021

Hak cipta dilindungi undang-undang

Skripsi ini tidak boleh diperbanyak seluruh atau sebagian,

Dengan dicetak ulang, difotokopi, atau cara lainnya tanpa izin dari penulis. 


\section{PERNYATAAN ORISINALITAS}

Dengan ini saya menyatakan bahwa skripsi dengan judul "Analisis Kinerja Keuangan Bank Umum Syariah di Indonesia Berdasarakan Islamicity Performance Index Periode 2015-2019” ini beserta seluruh isinya adalah benarbenar karya saya sendiri. Saya tidak melakukan penjiplakan atau pengutipan dengan cara-cara yang tidak sesuai dengan etika ilmu yang berlaku dalam masyarakat keilmuan. Atas pernyataan ini, saya siap menanggung resiko atau sanksi apabila di kemudian hari, jika ditemukan adanya pelanggaran etika keilmuan atau ada klaim dari pihak lain terhadap keaslian karya saya.

Bandung, Januari 2021

Yang Membuat Penyataan,

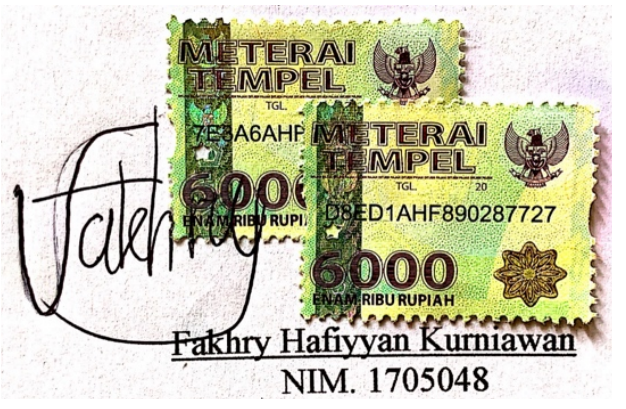




\section{LEMBAR PENGESAHAN}

\section{Judul Skripsi : Analisis Kinerja Keuangan Bank Umum Syariah di Indonesia Berdasarkan Islamicity Performance Index Periode 2015-2019 \\ Penyusun : Fakhry Hafiyyan Kurniawan \\ NIM : 1705048}

Program Studi : Ilmu Ekonomi dan Keuangan Islam

Bandung, Januari 2021

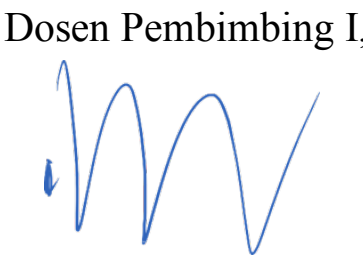

Dr. A. Jajang W. Mahri, M.Si. NIP. 196412031993021001
Dosen Pembimbing II,

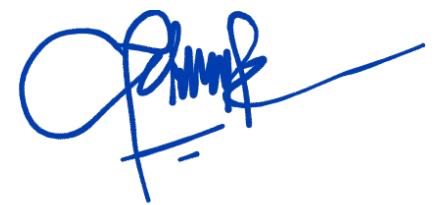

Rumaisah Azizah Al Adawiyah, S.E., M.Sc.

NIP. 920200119940524201

\section{Mengetahui,}

Ketua Program Studi Ilmu Ekonomi dan Keuangan Islam

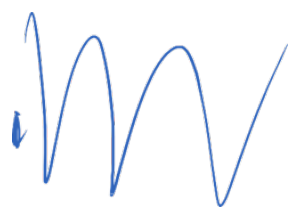

Dr. A. Jajang W. Mahri, M.Si.

NIP. 196412031993021001 


\section{LEMBAR ACC PERBAIKAN DRAFT SIDANG SKRIPSI}

Tanggal Ujian Skripsi : 05 Februari 2021

Nama

: Fakhry Hafiyyan Kurniawan

NIM

: 1705048

Judul Skripsi

: Analisis Kinerja Keuangan Bank Umum Syariah di Indonesia Berdasarkan Islamicity Performance Index Periode 2015-2019

Telah direvisi dan disetujui oleh para penguji skripsi:

\begin{tabular}{|c|c|c|}
\hline No. & Penguji Skripsi & Tanda Tangan \\
\hline 1. & Dr. Aas Nurasyiah, S.Pd., M.Si. \\
\hline 2. & Dr. Juliana S.Pd., M.E.Sy. \\
\hline 3. & Aneu Cakhyaneu, S.Pd., M.E.Sy. \\
\hline
\end{tabular}

Bandung, Februari 2021

Dosen Pembimbing I,

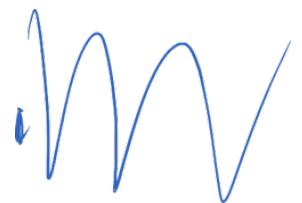

Dr. A. Jajang W. Mahri, M.Si. NIP. 196412031993021001
Dosen Pembimbing II,

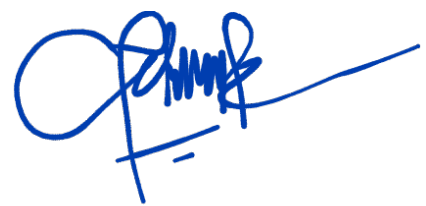

Rumaisah Azizah A, S.E., M.Sc. NIP. 920200119940524201

Mengetahui,

Ketua Program Studi Ilmu Ekonomi dan Keuangan Islam

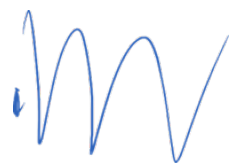

Dr. A. Jajang W. Mahri, M.Si.

NIP. 196412031993021001 
Fakhry Hafiyyan Kurniawan (1705048). "Analisis Kinerja Keuangan Bank Umum Syariah berdasarkan Islamicity Performance Index Periode 20152019", di bawah bimbingan Dr. A. Jajang W. Mahri, M.Si dan Rumaisah Azizah Al Adawiyah, S.E., M.Sc

\begin{abstract}
ABSTRAK
Bank Umum Syariah di Indonesia secara umum belum sepenuhnya melaksanakan kegiatan bisnis sesuai dengan ketentuan syariah. Oleh karena itu diperlukan suatu pengukuran kinerja yang mampu mengungkapkan nilai-nilai spiritual dan sosial yang terkandung dalam bank syariah. Tujuan penelitian ini adalah untuk mengetahui gambaran kinerja keuangan BUS berdasarkan Islamicity Performance Index. Penelitian ini merupakan penelitian kuantitatif dengan menggunakan analisis deskriptif. Data yang digunakan dalam penelitan ini adalah data sekunder. Populasi penelitian ini adalah BUS di Indonesia periode 2015-2019, dengan sampel sebanyak dua belas bank. Penarikan sampel dilakukan dengan menggunakan metode purposive sampling. Hasil penelitian menunjukan Bank Panin Dubai Syariah merupakan bank yang paling baik dalam indikator PSR. Nilai ZPR pada BUS di Indonesia masih rendah. BNI syariah merupakan bank syariah yang memiliki nilai skor tertinggi pada indikator ZPR. EDR menunjukan bahwa Bank Syariah Mandiri memiliki nilai rata-rata yang paling tinggi. Pada indikator DEWR menunjukan bahwa Bank BTPN Syariah memiliki tingkat kesenjangan antar direktur dan karyawan yang cukup tinggi. IIR dan IsIR BUS menunjukan bahwa secara umum telah melaksanakan kinerja bisnis pada sektor halal. Sedangkan secara keseluruhan memperoleh predikat cukup memuaskan. Penelitian ini diharapkan dapat dijadikan bahan pertimbangan bagi instansi terkait untuk menerapkan pengukuran kinerja BUS yang sesuai dengan konsep Islamicity Performance Index serta dijadikan bahan pertimbangan dalam mengambil langkahlangkah kebijakan yang sesuai dengan konsep syariah yang akan digunakan kedepannya.
\end{abstract}

Kata Kunci: Kinerja Keuangan, Kinerja Syariah, Islamicity Performance Index, Bank Umum Syariah 
Fakhry Hafiyyan Kurniawan (1705048). "Analysis of the Financial Performance of Islamic Commercial Banking in Indonesia Based Islamicity Performance Index for the 2015-2019 periods", under the guidance of Dr. A. Jajang W. Mahri, M.Si and Rumaisah Azizah Al Adawiyah, S.E., M.Sc

\begin{abstract}
Islamic Commercial Banking in Indonesia generally has not fully carry out business activities in accordance with the provisions of sharia. Therefore we need a performance measurement that is able to express spiritual values and social embodied in Islamic banks. The purpose of this study is to describe the performance of Islamic banking based Islamicity Performance Index. This research is a quantitative research using descriptive analysis. The data used in this research is secondary data. The study population was Islamic banks in Indonesia during the period 2015-2019, with a sample of twelve banks. Sampling was done by using purposive sampling method. The results showed Bank Panin Dubai Sharia Bank's the best bank in the PSR.Value performance ratio zakat on Islamic banking in Indonesia is still low. BNI Sharia is a bank that has a value of the highest average for the ZPR indicator. EDR indicates that Mandiri Sharia Bank has an average value of the most high. DEWR shows that BTPN Sharia have fairly high levels of disparity between directos and employees. IIR and IsIR shows that in general Islamic commercial banks in Indonesia has showed in general have carried out businesss performance in the halal sector. Meanwhile, on the wole, it received a satisfactory predicate. This research is expected to be taken into consideration for the related institutions to apply the performance measurement of Islamic Commercial Banking in accordance with the concept of Islamicity Performance Index and be taken into consideration in taking policy measures in accordance with the concept of sharia which will be used in the future.
\end{abstract}

Keywords: Financial Performance, Sharia Performance, Islamicity Performance Index, Islamic Commercial Banking 


\section{KATA PENGANTAR}

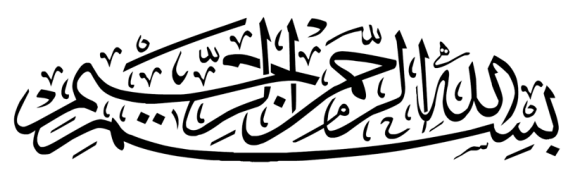

Assalamu'alaikum warahmatullahi wabarakatuh,

Puji syukur kami panjatkan kehadirat Allah SWT yang telah memberikan rahmat dan hidayah-Nya sehingga skripsi yang berjudul "Analisis Kinerja Keuangan Bank Umum Syariah di Indonesia Berdasarkan Islamicity Performance Index Periode 2015-2019" selesai. Skripsi ini disusun dalam rangka memenuhi syarat memperoleh gelar Sarjana Ekonomi pada Program Studi Ilmu Ekonomi dan Keuangan Islam

Dalam menyusun Skripsi ini, penulis menyadari masih jauh dari sempurna. Oleh sebab itu penulis mengharapkan saran dan kritik yang bersifat positif dan konstruktif sehingga dapat dijadikan bahan koreksi. Semoga skripsi ini bermanfaat dan dapat diterima dengan baik oleh para pembacanya.

Akhir kata, penulis sampaikan terimakasih kepada semua pihak yang telah berperan serta dalam penyusunan skripsi ini dari awal hingga akhir.

Wassalamualaikum warahmatullahi wabarakatuh.

Bandung, Januari 2021

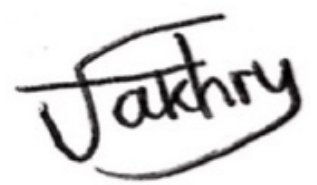

Fakhry Hafiyyan Kurniawan

NIM. 1705048 


\section{UCAPAN TERIMA KASIH}

Alhamdulillaahirabbil'aalamiin, penulis panjatkan puji dan syukur kepada Allah SWT yang telah memberikan kenikmatan dan karunia yang tak terhingga, hingga saat ini penulis dapat menyelesaikan skripsi ini. Penulis menyadari bahwa penyelesaian skripsi ini tidak akan terwujud tanpa ada dukungan dari berbagai pihak, baik secara moril maupun materil. Sehingga pada kesempatan ini, penulis ingin mengucapkan terima kasih yang sebesar-besarnya kepada pihak-pihak yang telah terlibat dalam masa perkuliahan sampai proses penyusunan skripsi ini hingga selesai. Oleh karena itu, sudah selayaknya penulis mengucapkan terima kasih kepada:

1. Bapak Prof. Dr. M. Solehuddin, M.Pd., M.A. selaku Rektor Universitas Pendidikan Indonesia.

2. Bapak Prof. Dr. H. Eeng Ahman, M.S. selaku Dekan Fakultas Pendidikan Ekonomi dan Bisnis.

3. Bapak Dr. A. Jajang W. Mahri, M.Si, selaku Ketua Program Studi Ilmu Ekonomi dan Keuangan Islam serta Dosen Pembimbing 1 dalam penyusunan skripsi yang selalu membantu, mengarahkan, membimbing, meluangkan waktu dan berbagi ilmu sebagai bekal dalam proses pembuatan skripsi.

4. Ibu Aneu Cakhyaneu, S.Pd., M.E.Sy, selaku Dosen Pembimbing Akademik yang telah mengarahkan sekaligus memberi nasihat yang baik selama masa perkuliahan.

5. Ibu Rumaisah Azizah Al Adawiyah, M.Sc., selaku Dosen Pembimbing skripsi 2 yang telah meluangkan waktu, ilmu dan tenaga dimulai dari membimbing dalam penyusunan DBS atau proposal, serta skripsi dengan penuh kesabaran dan pengertian.

6. Segenap Dosen Ilmu Ekonomi dan Keuangan Islam yaitu Bapak Dr. Juliana, S. Pd., M.E.Sy, Ibu Dr. Aas. Nurasyiah, M.Si., Bapak Firmansyah, S.Pd., M.E.Sy., Ibu Neni Sri Wulandari, S.Pd., M.Si., Ibu Rida Rosida, B.Sc., M.Sc., Ibu Suci Apriliani Utami, S.Pd., M.E.Sy., Ibu Hilda Monoarfa, M.Si., dan Ibu Fitranty Adirestury, S.Pd., M.Si., yang sangat berjasa dengan sabar untuk berbagi ilmu serta pengalaman kepada penulis selama masa perkuliahan. 
7. Ibu Lela selaku Staff Administrasi Program Studi Ilmu Ekonomi dan Keuangan Islam yang telah banyak membantu penulis dalam hal administrasi selama proses perkuliahan dan dalam penyelesaian studi ini.

8. Kedua orang tua penulis yaitu Bapak Kurnia Sadikin dan Ibu Yuli Nuriyanti yang selalu mendoakan penulis, mendidik penulis untuk menjadi lebih baik, selalu ada dalam keadaan apapun baik suka maupun duka, memberikan dukungan moril maupun materil serta memberikan kasih sayang dalam keadaan apapun. Terima kasih atas segala yang telah diberikan, sehingga penulis dapat menyelesaikan skripsi ini. Semoga Papah dan Mamah selalu diberikan kesehatan dan selalu dalam lindungan Allah SWT.

9. Adik kandung tersayang penulis yaitu Fariq Hafizhan Kurniawan, Frisya Salsabila Khaerunnisa dan Faezya Shakila Khairina yang selalu menguatkan penulis untuk terus semangat dan selalu menghibur dalam proses penyusunan skripsi.

10. Keluarga besar penulis terutama Fasya Hafifah Thohiroh dan Faizal Fadillah Kadarusman yang selalu senantiasa memberikan dukungan, bantuan, dan memberi semangat yang tidak terhingga bagi penulis dalam menyelesaikan penulisan skripsi ini. Semoga kalian semua selalu dalam lindungan Allah SWT

11. Hadi Kostaman, selaku sahabat seperjuangan dari awal masa perkuliahan yang selalu memberikan penulis semangat, selalu ada dalam keadaan suka dan duka, selalu bisa untuk menciptakan tawa. Semoga sukses dan sehat selalu serta dalam lindungan Allah SWT.

12. Sahabat-sahabat lainnya yang selalu menemani, menghibur, mendengar segala keluh kesah selama masa perkuliahan, yaitu Hilna Kuspiana, Rizkia Ramadhani, Syaimaya Fadhillah, Ega Firryal Herdidewayanti, Venny Adelia Nadianshafira, Hilma dan Femila Sefti Damayanthi. Terima kasih atas kebersamaan selama 4 tahun ini. Semoga sukses dan sehat selalu serta dalam lindungan Allah SWT.

13. Hartawati dan sahabat Universitas Kristen Maranatha lainnya, yang selalu memberikan dukungan, bantuan, dan memberi semangat yang tidak terhingga bagi penulis dalam menyelesaikan penulisan skripsi ini. Semoga sukses dan sehat selalu serta dalam lindungan Allah SWT. 
14. Sahabat SMPN 1 Baleendah dan Universitas Komputer Indonesia terhebat yang selalu memberikan tawa dan pengalaman berharga, yaitu Elsa Ainun Pangesti, Sopan Sopian, Faisal Fatchurrahman, Muhamad Haris, Maulana Malik Rizqian, Alm. Lulu Meilita, Muhammad Zulfiqry, Gunawan Wibisono dan Riana Arnetha. Semoga kalian sehat selalu, sukses dan selalu dalam lindungan Allah SWT.

15. Sahabat SMAN 11 Bandung yang selalu setia menemani penulis dikala suka dan duka, yaitu Revira Puspasuci Amelia, Hedi Hardika, Egya Alianti dan Andrian Gunawan. Semoga kalian sehat selalu, sukses dan selalu dalam lindungan Allah SWT.

16. Keluarga Atase Perdagangan KBRI Manila, yaitu Bapak Lazuardi Nasution, Ibu Renny Miranty, Mas Titanicko, Mba Dinda Ayudhita dan Mas Yonathan Ade yang telah memberikan pengalaman berharga.

17. Bapak Widya Rahmanto dan Mba Ainulia Paramita selaku Wakil dan Sekretaris Duta Besar KBRI Manila yang telah memberikan banyak pengalaman dan cerita yang berharga.

18. Keluarga besar KBRI Manila Filipina yang telah memberikan banyak kenangan dan pengalaman berharga.

19. Terima kasih kepada diri sendiri yang tidak pantang menyerah, kamu ternyata hebat.

20. Seluruh keluarga dan pihak yang telah membantu dan mendoakan penulis yang tentunya tidak dapat disebutkan satu persatu. Terima kasih atas segala doa dan bantuaannya.

Akhir kata, semoga Allah SWT memberikan balasan dunia dan akhirat yang berlipat ganda atas segala kebaikan dan bantuan yang telah diberikan kepada penulis dalam menjalankan dan menyelesaikan proses akademik di Program Studi Ilmu Ekonomi dan Keuangan Islam, FPEB, UPI, khususnya dalam penyelesaian skripsi ini. Aamiin Ya Rabbal'alamiin. 


\section{DAFTAR ISI}

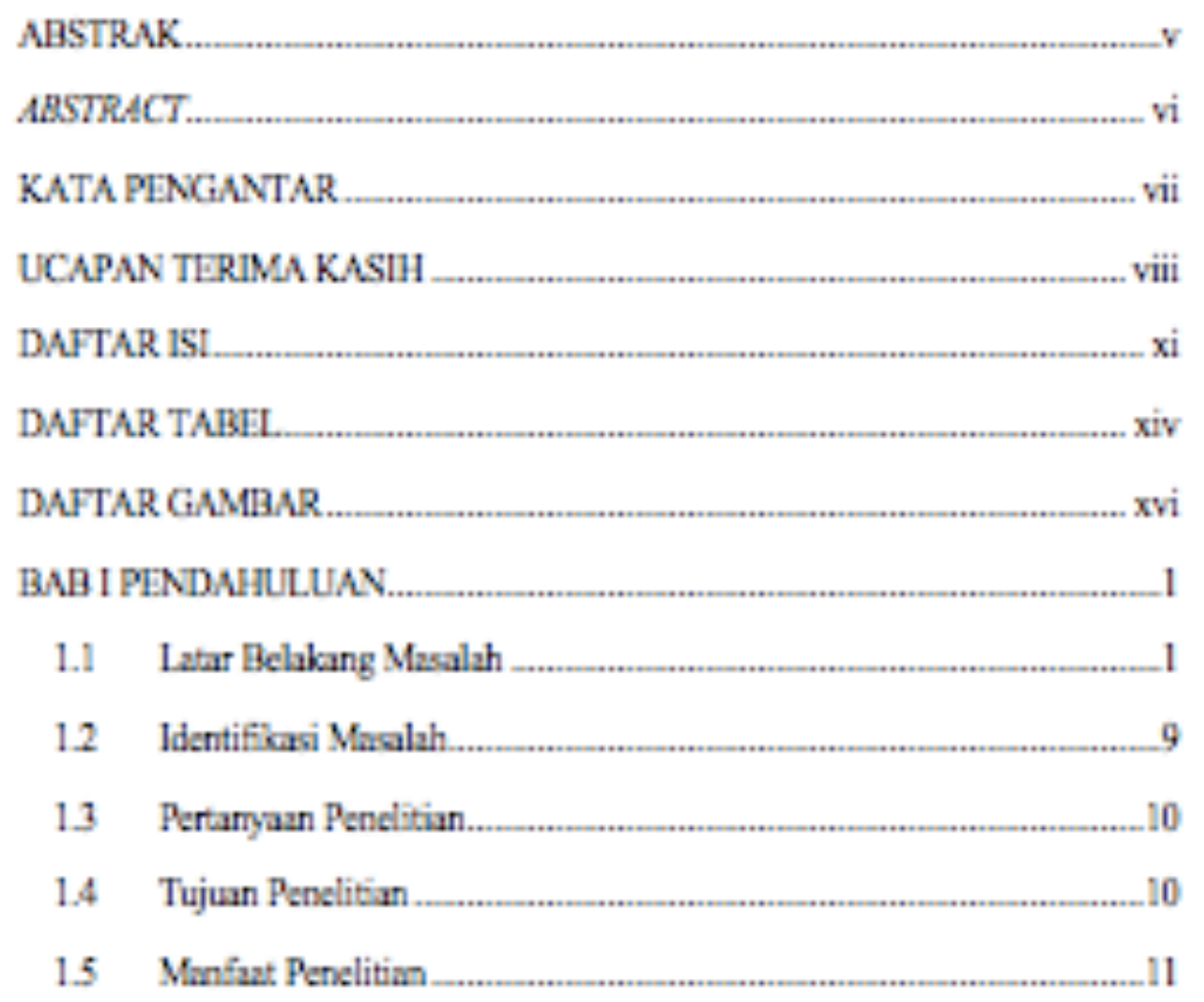

BAB II TINJAUAN PUSTAKA, KERANGKA PEMIKIRAN

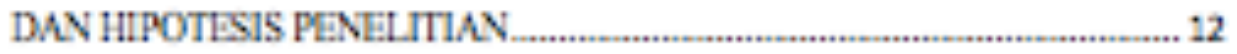

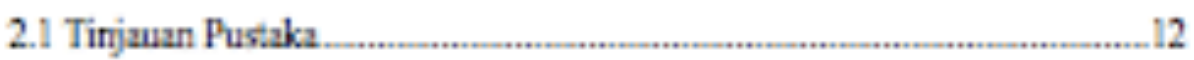

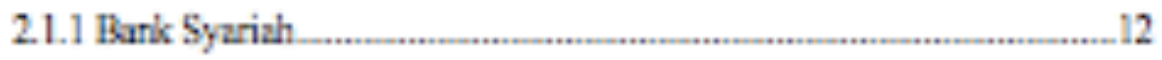

2.1.2 Kinerj.

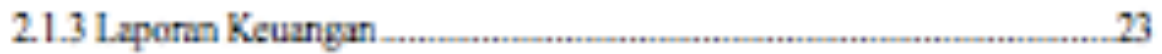

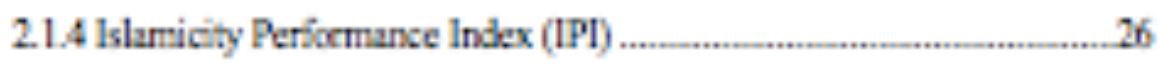

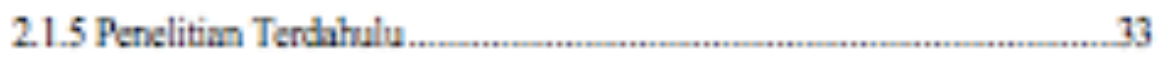

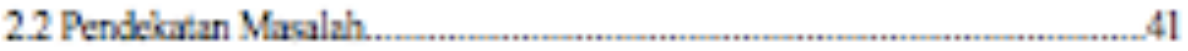

BAB III OBJEK, METODE DAN DESAIN PENELTLAN__..._..............4

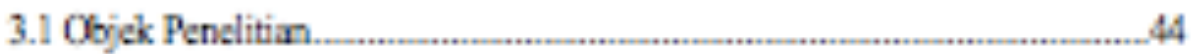

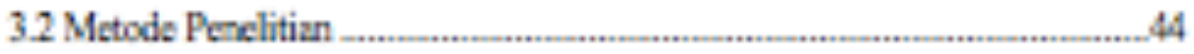


3.3 Dessin Penelitian _..........................................................

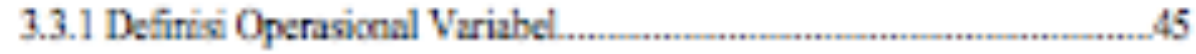

3.3.2 Populasi dan Sampel Penelitian..._................................47

1.3.3 S.mber Deta dn Teknik Pengumpulan Deta..........................49

3.3.4 Teknik Analisis Drta..._...._......................................

BAB IV HASIL. PENELITLAN DAN PEMBAHASAN_...__...__...........56

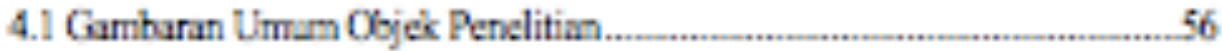

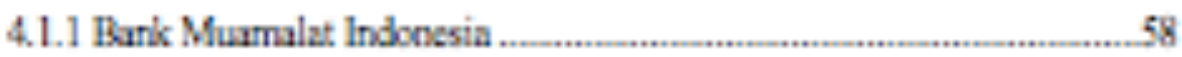

4.1.2 Bank Syzriah Mandri._....._...__........._.................. 59

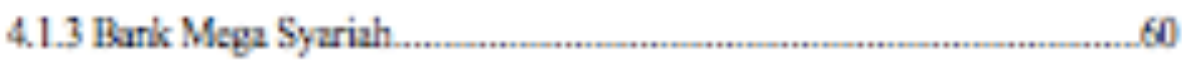

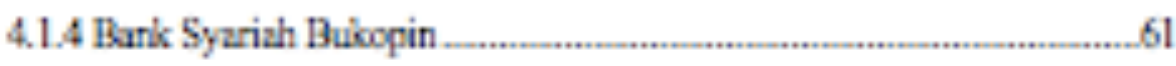

4.1.5 Rark BRI Syariah _.................................................

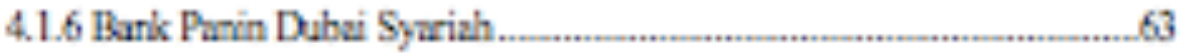

4.1.7 Bank Jabur Banten Syariah . _....................................64

4.1.8 Bank Victoria Syariah..................................................

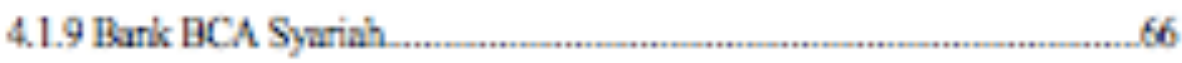

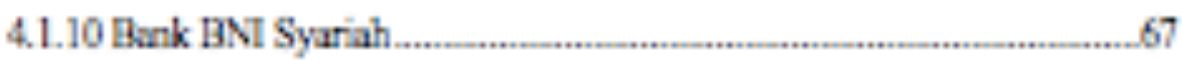

4.1.11 Bank Net Syariah Indonesia_.......................................68

4.1.12 Bank Tahungan Pensiunan Syrriah ..._.............._............69

4.2 Deskripsi Hasil Penelitian........_....._...............................

4.2.1 Kinerja Islamicity Performance Index pada Bank Umum Syariah di

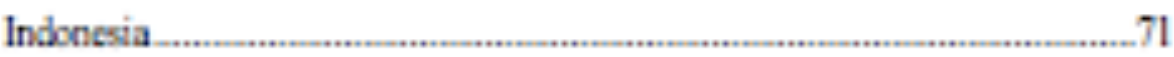

4.3 Pembahasan

BAB V SIMPULAN, EMPLIKASI DAN REKOMENDASI__..__.............95

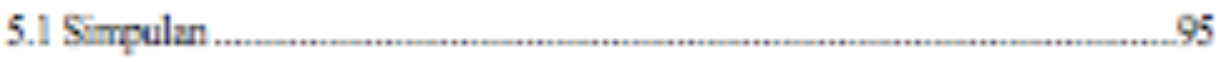

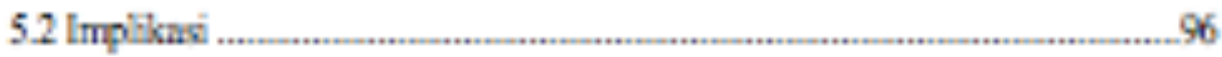

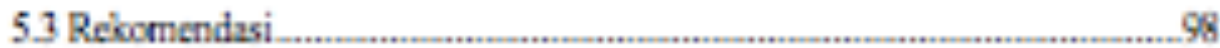

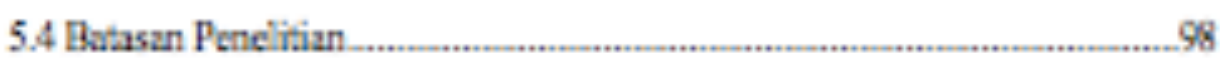

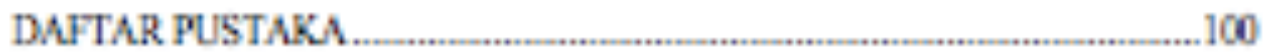




\section{DAFTAR TABEL.}

Tabel 1.1 Kinerja Perhunkan Syariah di Indonesiz Periode tahun 2015 - 2019

(Miliar Rupiah)

Tabel 1.2 Jaringan Kantor Perbunkan Syariah di Indonesia _....................... 2

Tabel 1.3 Perkembongen dan Capaim Profitabilitas Bank Umum Syariah (BUS)

(dalam persen)

Tabel 1.4 Total Penyaluran Dra Zakat Pada Bank Umum Sycriah di Indonesia

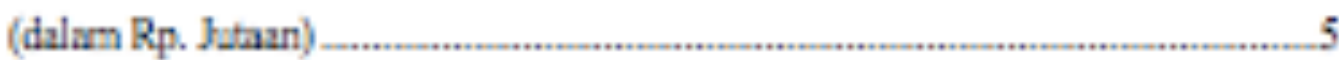

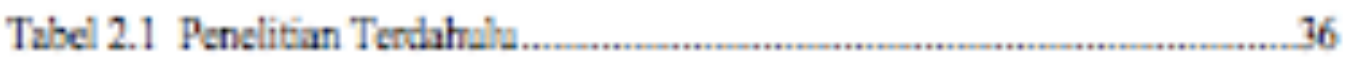

Tabel 3.1 Definisi Operasional Variabel .......................................43

Tabel 3.2 Daftar Populas Penelitian .........._.........._.......................46

Tabel 3.3 Daftar Sampel Penclitian ....................._.......................47

Tabel 3.4 Standar Penilaim lshamicity Performance lndex._......................49

Tabel 3.5 Penilzian Prodikat Islamicity Peffocmance Inder _.....................52

Tabel 4. 1 Dafar Bank Umum Syariah (BUS) Berdasarkan Tanggal Berdiri.....55

Tabel 4.2 Totzl Pembiayaun Bagi Hasil dn Total Penyzluran Dana Zakat Bank

Muamalat Indonesia 2015-2019 (Miliar Rupiah) __...___.___..._............57

Tabel 4.3 Totzl Pembiayan Bagi Hasil dn Toal Penyzluran Dana Zakat Bank

Syariah Mandiri 2015-2019 (Miliar Rupiah)_....__...__...__................58

Tabel 4.4 Totzl Pembiayaun Bagi Hasil dn Total Penyzluran Dena Zakat Bank

Mega Syariah 2015-2019 (Miliar Rupiah)...__...._...__...__..._...._.........59

Tabel 4.5 Totzl Pembiayaun Bagi Hasil dn Toal Penyaluran Dana Zakat Bank

Syariah Bukop̧in 2015-2019 (Miliar Rupiah)

Tabel 4.6 Totzl Pembiayaun Bagi Havil dn Total Penyzluran Dena Zakat Bank

BRI Syariah 2015-2019 (Maliar Rupiah). 61

Tabel 4.7 Total Pembiayan Bagi Hasil dn Total Penyzluran Dans Zakat Bank

Panin Dubai Syariah 2015-2019 (Miliar Rupiah).

Tabel 4.8 Total Pembiayan Bagi Hasil dn Total Penyaluran Dana Zakat Bank

BNB Syariah 2015-2019 (Miliar Rupiah).

Tabel 4.9 Total Pernbayanan Bagi Hasil dn Total Penyzluran Dens Zakat Rank

Victoria Syariah 2015-2019 (Miliar Rupiah) 
Tabel 4.10 Total Pembiayan Bagi Hzsil dan Toal Penyalurn Dana Zakat Bank BCA Syariah 2015-2019 (Miliar Rupiah). 65

Tabel 4.11 Total Pembiasaan Bagi Hasil dan Toal Penyalurm Dana Zakat Bank BNI Syariah 2015-2019 (Miliar Rupiah). 66

Tabel 4. 12 Toal Permbizyan Bagi Hasil dan Total Penyaluran Dana Zakat Bank Net Syarizh Indonesiz 2015-2019 (Niliar Rapiah) 67

Tabel 4. 13 Total Pernbizyan Bagi Hasil dan Total Penyalura Dana Zakat Bank BPTN Syariah Indonesia 2015-2019 (Miliar Rupiah) ._._..._...._...............68

Tabel 4.14 Hasil Petitungm PSR (dalam \%)..............................69

Tabel 4.15 Hasil Pehitungm ZPR (dzlam \%)................................ 71

Tabel 4.16 Hasil Pethiturgm Qundh (dzalam \%) ............................... 72

Tabel 4.17 Hasil Pehitungm Employee Expense (dalam \%) ......................73

Tabel 4.18 Hasil Petitungm Sharcholder (dalam \%) _......................... 75

Tabel 4.19 Hasil Pethitungan Net Procit (dzlam \%)...._.........................76

Tabel 4.20 Hasil Pehitungm EDR (dalam \%)................................ 77

Tabel 4.21 Hasil Pehitungm DEWR (dalam kali) .............................. 78

Tabel 4.22 Hasil Pehitungm IIR (dhlam \%)_........._......................... S0

Tabel 4.23 Hasil Pehitungm LsIR (dahm \%) ..................................80

Tabel 4.24 Hasil Pehitungm lndikztor IPI Bank Umum Syariah di Indonesia.. S2 Tabel 4.25 lslanicity Perócmance Index Brok Limum Syariah d Indonesiz .....83 


\section{DAFTAR GAMBMR}

Gamhar 1.1 Pemhizyzm Bage Hasil Bank Umum Syariah di Indonesia............4

Gembar 21 Pendekatan Masalah _..........................................41

Gamhar 4. 1 Analisis Tren Profit Sharing Ratio BUS __.........................85

Gamhar 4. 2 Analisis Tren Zakat Performance Ratio............................ 8

Gamhar 4. 3 Analisis Tren Equitable Distribution Ratio.........................87

Gambar 4.4 Analisis Tren Director-Employee Welfure Ratia...._....._...........88

Gamhar 4. 5 Analisis Tren Islamic Investment Vs Non Lshamic Imestment......90

Gumbar 4.6 Analisis Tren Lslamic Inoome Vs Non Islamic Income ................91

Gamhar 4.7 Islanricity Performance Index Bank Umum Syariah di Indonesia...92 


\section{DAFTAR PUSTAKA}

Aisjah, S., \& Hadianto, A. E. (2013). Performance Based Islamic Performance Index (Stduy on the Bank Muamalat Indonesia and Bank Syariah Mandiri). Asia - Pacifif Management and Business Aplication 2 (2) , 98 - 110.

Aisjah, Siti; Hadianto, Agustian Eko. (2013). Performance Based Islamic Performance Indes (Study on the Bank Muamalat Indonesia and Bank Syariah Mandiri). Journal: Asia-Pacifif Management and Business Application.

Akbar, S. (2018). Analisa Faktor - Faktor yang Mempengaruhi Kinerja Karyawan. JIAGANIS, Vol.3, No.2.

Akramunnas, \& Kara, M. (2019). Pengukuran Kinerja Perbankan Dengan Metode CAMEL. Jurnal Al-Mashrafiyah, Vol.3, No.1, 57 - 69.

Al - Haritsi, J. (2014). Fikih Ekonomi Umar bin Al-Khathab. Jakarta: Pustaka AlKautsar.

Almunawwaroh, M. (2018). Pengaruh CAR, NPF dan FDR terhadap Profitabilitas Bank Syariah di Indonesia. Universitas Siliwangi.

Andraeny, D., \& Putri, D. D. (2017). Islamicity Financial Performance Index in Indonesian Islamic Banks. Shirkah: Journal of Economics and Business.

Andrianto, \& Firmansyah, A. (2019). Manajemen Bank Syariah (Implementasi Teori dan Praktek). Pasuruan: Qiara Media Partner.

Anshori, A. G. (2018). Perbankan Syariah di Indonesia. Yogyakarta: Gadjah Mada University Press.

Anshori, M. (2017). Metodologi Penelitian Kuantitatif,Cetakan Pertama. Surabaya: Airlangga University Press.

Anshori, M., \& Iswati, S. (2009). Metodologi Penelitian Kuantitatif. Surabaya: Pusat Penerbitan dan Percetakan UNAIR (AUP).

Antonio, M. S. (2009). Dasar - Dasar Manajemen Bank Syariah. Tangerang: Azkia Publisher.

Aryani, D. S., \& dkk. (2019). Ekonomi Syariah: Dengan Pendekatan Hasil Penelitian. Cirebon: Nusa Litera Inspirasi. 
Badri, R. E. (2019). Analisis Perbandingan Kinerja Bank Syariah Mandiri dan Bank Muamalat Indonesia Menggunakan Islamicity Performance Index tahun 2015 - 2017. Ekuivalensi: Jurnal Ekonomi Bisnis.

Bank BJB Syariah. (2015 - 2019). Retrieved from Annual Report Bank BJB Syariah 2015 - 2019: http://www.bjbsyariah.co.id/annual-report

Bank Bukopin Syariah. (2015 - 2019). Retrieved from Annual Report Bank Bukopin Syariah 2015 - 2020: https://www.syariahbukopin.co.id/id/laporan

Bank Indonesia. (2005). Bank Syariah: Gambaran Umum. Jakarta: Pusat Pendidikan dan Studi Kebanksentralan (PPSK) Bank Indonesia.

Bank Mega Syariah. (2015 - 2019). Retrieved from Annual Report Bank Mega Syariah 2015 - 2019: https://www.megasyariah.co.id/

Bank Muamalat Indonesia. (2015 - 2019). Retrieved from Annual Report Bank $\begin{array}{llll}\text { Muamalat } & \text { Indonesia } & 2015 & -\end{array}$

https://www.bankmuamalat.co.id/en/investor-relations/annual-report

Bank Net Syariah. (2015 - 2019). Retrieved from Annual Report Bank Net Syariah 2015 - 2019: https://banknetsyariah.co.id/maybank-annual-report/flip/0

Bank Panin Dubai Syariah. (2015 - 2019). Retrieved from Annual Report Bank Panin Dubai Syariah $2015 \quad$ - 2019 : https://paninbanksyariah.co.id/index.php/mtentangkami/laporantahunan Bank Victoria Syariah. (2015 - 2019). Retrieved from Annual Report Bank Victoria Syariah 2015 - 2019: https://bankvictoriasyariah.co.id/page/sub/tahunan bareksa. (2019, Desember 09). Retrieved from OJK: Sinergi dengan Bank Umum, Market Share Bank Syariah Bisa Terus Meningkat: https://www.bareksa.com/berita/id/text/2019/12/09/ojk-sinergi-denganbank-umum-market-share-bank-syariah-bisa-terus-meningkat/23788/news Bauw, A., \& Gunawati, N. D. (2018). Faktor - Faktor Yang Mempengaruhi Kinerja Pegawai Kementerian Agama Kabupaten Keerom. Future: Jurnal Manajemen dan Akuntansi.

BCA Syariah. (2015 - 2019). Retrieved from Annual Report BCA Syariah 2015 2019: https://www.bcasyariah.co.id/laporan-keuangan/tahunan/2019-3/ 
BNI Syariah. (2015 - 2019). Retrieved from Annual Report Bank BNI Syariah 2015 2019:

https://www.bnisyariah.co.id/id-

$\mathrm{id} /$ perusahaan/hubunganinvestor/laporanpresentasi/laporantahunan

Bombang, S. (2013). Prospek Perbankan Syariah di Indonesia. Jurnal Diskursus Islam, Vol.1 No.2, 286 - 287.

BRI Syariah. (2015 - 2019). Retrieved from Annual Report Bank BRI Syariah 2015

- 2019: https://www.brisyariah.co.id/tentang_hubInvestor.php?f=annual

BSM. (2015 - 2019). Annual Report Bank Syariah Mandiri. Retrieved from https://www.mandirisyariah.co.id/tentang-kami/company-report/annualreport

Budiono, A. (2017). Penerapan Prinsip Syariah Pada Lembaga Keuangan Syariah. Jurnal Law and Justice, Vol.2 No.1.

Bungin, B. (2017). Metodologi Penelitian Kuantitatif: Komunikasi, Ekonomi, dan Kebijakan Publik Serta Ilmu - Ilmu Sosial Lainnya, Edisi Kedua. Jakarta: Kencana.

Cakhyaneu, A. (2018). Pengukuran Kinerja Bank Umum Syariah di Indonesia Berdasarkan Sharia Maqashid Index (SMI). Amwaluna: Jurnal Ekonomi dan Keuangan Syariah Vol.2,No.2, 154 - 165.

Devita, M. (2017). Faktor - Faktor Yang Mempengaruhi Kinerja Karyawan di Restaurant Alpha Hotel Pekanbaru. JOM FISIP, Vol.4, No.2.

Dewi, M. S., \& Trihastuti, A. (2016). Penilaian Kualitas Kinerja Keuangan Perusahaan Perbankan antara Sebelum dan Sesudah Merger Studi Kasus Pada PT. Bank Mandiri, Tbk. Jurnal Ekonomi dan Akuntasi, 21 - 36.

Dinaroe, Mulya, I., \& Mutia, E. (2019). Islamicity Financial Performance Index Perbankan Syariah di Indonesia. Jurnal Perspektif Ekonomi Darussalam, Vol.5, No.1.

Duli, N. (2019). Metodologi Penelitian Kuantitafif: Beberapa Konsep Dasar Untuk Penulisan Skripsi dan Analisis Data dengan SPSS. Yogyakarta: Deepublish Publisher.

Endrasprihatin, R. (2014). Rancangan Sistim Manajemen Kinerja Pada PT X. Jurnal Administrasi Kantor, Vol.2, No.2. 
Fatmasari, R., \& Kholmi, M. (2018). Analisis Kinerja Keuangan Perbankan Syariah dengan Pendekatan Islamicity Performance Index pada Perbankan Syariah di Indonesia. Jurnal Akademi Akuntansi, Vol.1 No.1, 78.

Fauzan. (2011). Analisis Kinerja Keuangan Pada Perbankan Syariah. MODERNISASI, Vol. 7 No.3.

Firdausi, I. (2016). Analisis Pengaruh Kinerja Perbankan Terhadap Dana Pihak Ketiga Bank Persero. Jurnal Keuangan dan Perbankan, Vol.20, No.3.

Hadi, M. (2019). Paradigma Masterpiece Keuangan Islam dan Aplikasinya di Perbankan Syariah. Yogyakarta: Deepublish Publisher.

Hamdani. (2018). Teori dan Praktik Pengambilan Keputusan dalam Perspektif Manajemen dan Akuntansi. Jakarta: Mitra Wacana Media.

Hamdi, A. S. (2015). Metode Penelitian Kuantitatif Aplikasi dalam Pendidikan. Yogyakarta: Deepublish.

Hameed, S., Wirman, A., Alrazi, B., Nazli, M., \& Pramono, S. (2004). Alternative Disclosure \& Performance Measures For Islamic Banks. Malaysia: Department of Accounting International Islamic University Malaysia, 19.

Hameed, Shahul; , dkk. (2004). Alternative Disclosure \& Performance Measures for Islamic Banks. Interantional Islamic University Malaysia, Kuala Lumpur.

Hantono. (2018). Konsep Analisisa Laporan Keuangan dengan Pendekatan Rasio dan SPSS. Yogyakarta: CV Budi Utama.

Haq, F. I. (2015). Analisis Perbandingan Kinerja Bank Syariah di Indonesia Melalui Islamicity Performance Index. Jurnal Ilmiah UB.

Harkaneri, \& Reflisa, H. (2018). Pendapatan Non Halal sebagai Sumber dan Penggunaan Qardhul Hasan dalam Perspektif Islam. SYARIKAT: Jurnal Rumpun Ekonomi Syariah, Vol.1 No.2, 105.

Haryono, S. (2018). Manajemen Kinerja SDM . Yogyakarta: Luxima Metro Media.

Hasibuan, A. N., Annam, R., \& Nofinawati. (2020). Audit Bank Syariah. Jakarta: Kencana.

Heridiansyah, J., \& Redjeki, D. S. (2012). Manajemen Kinerja Sebagai Media Perubahan. Jurnal STIE Semarang, Vol.4 No.3.

Hery. (2015). Analisis Kinerja Manajemen. Jakarta: Grasindo. 
https://www.kompasiana.com/gamelf/584f31cf3e23bd7827c42674/bank-syariahsudah-benarbenar-syariah

Ikhwal, N. (2016). Analisis ROA dan ROE terhadap Profitabilitas di Bursa Efek Indonesia. Al Masraf: Jurnal Lembaga Keuangan dan Perbankan, Vol.1 No.2, 213 - 214.

Indonesia, I. B. (2018). Mengelola Bank Syariah: Modul Sertifikasi Tingkat II General Banking Syariah. Jakarta: PT Gramedia Pustaka Utama.

Irawati, R. S., \& Mustikowati, R. I. (2012). Penilaian Kinerja Keuangan Perbankan Syariah Melalui Pendekatan Capital, Asset, Earnings, Liquidity, Risiko Usaha dan Efisiensi Usaha. MODERNISASI, Vol.8, No.1.

Ismail. (2017). Perbankan Syariah. Jakarta : Kencana .

Ismail. (2018). Manajemen Perbankan: Dari Teori Menuju Aplikasi. Jakarta: Prenadamedia Group.

Juliana, J. (2016). Preferensi Nasabah Memilih Bank Syariah Dilihat dari Aspek Karakteristik Nasabah. E-Qien: Jurnal Ekonomi dan Bisnis, Vol.4 No.1.

Juliana, J., Faathir, M., \& Sulthan, M.A. (2019). Implementasi Etika Bisnis Islam Pelaku Usaha Mikro : Studi Kasus Pada Pelaku Usaha Mikro Syariah Puspa Bank Indonesia Wilayah Jawa Barat Di Bandung Tahun 2017. Strategic: Jurnal Pendidikan Manajemen Bisnis, Vol.19, No.1.

Iswari, P. W., \& Amanah. (2015). Kinerja Keuangan Bank Umum Syariah: Negara Vs Swasta. Jurnal Islaminomic, Vol.6, No.2.

Karim, A. (2018). Persepsi Masyarakat Jepara Tentang Makna Asar As-Sujud (Studi Living Qur'an QS. Al-Fath Ayat 29). Hermeneutik: Jurnal Ilmu AlQur'an dan Tafsir, Vol.12, No.02.

Kariyoto. (2017). Analisa Laporan Keuangan . Malang: UB Press.

Kawatu, F. S. (2019). Analisis Laporan Keuangan Sektor Publik. Yogyakarta: Deepublish.

Kompasiana.com. (2016, Desember 13). Retrieved from Bank Syariah, sudah benar - benar syariah?:

Kristiyanti, M. (2012). Peran Indikator Kinerja dalam Mengukur Kinerja Manajemen. Majalah Ilmiah INFORMATIKA, Vol.3, No.2. 
Kusjainah, \& Listyorini, I. (2015). Faktor - Faktor yang Mempengaruhi Kinerja Karyawan: Model Pengujian Dengan Variabel Mediasi. Jurnal Telaah Bisnis, Vol.16, No.1.

Lenap, I. P. (2019). Pengungkapan Pendapatan Non-Halal: PSAK 109 vs Praktik. Jurnal JAA, Vol.3 No.2, 96.

Listiani, T. (2011). Manajemen Kinerja, Kinerja Organisasi Serta Implikasinya Terhadap Kualitas Pelayanan Organisasi Sektor Publik. Jurnal Ilmu Administrasi, Vol.VIII, No.3.

Listiani, Y. U., Nurhasanah, N., \& Bayuni, E. M. (2016). Pengaruh Islamicity Performance Index terhadap Profitabilitas Bank Jabar Banten Syariah Periode 2011 - 2014. Prosiding Keuangan dan Perbankan Syariah, Vol.2,No.2, 576.

Lutfiandari, H. A., \& Septiarini, D. F. (2016). Analisis Tren dan Perbandingan Rasio Islamicity Performance pada Bank Syariah Mandiri, Bank Muamalat Indonesia, Bank BRI Syariah dan Bank BNI Syariah Periode 2011 - 2014. Jurnal Ekonomi Syariah Teori dan Terapan Vol.3 No.6, 430.

Makruflis, M. (2019). Pengukuran Kesehatan Bank Syariah Berdasarkan Islamicity Performance Index (Studi Pada BMI dan BSM Kota Pekanbaru Riau). IQTISHADUNA: Jurnal Ilmiah Ekonomi Kita,Vol.8 No.2.

Makruflis, Muhammad. (2019). Pengukuran Kesehatan Bank Syariah berdasarkan Islamicity Performance Index (Studi Pada BMI dan BSM Kota Pekanbarau Riau). Jurnal Iqtishaduna: Jurnal Ilmiah Ekonomi Kita, 229.

Meilani, S. E., \& dkk. (2016). Analisis Kinerja Perbankan Syariah di Indonesia Menggunakan Pendekatan Islamicity Indices. Seminar Nasional dan The3rd Call for Syariah Paper.

Meilani, S. R., Andraeny, D., \& Rahmayati, A. (2015). Analisis Kinerja Perbankan Syariah di Indonesia dengan Menggunakan Pendekatan Islamicity Indicies. In Syariah Paper Accounting FEB UMS, 22 - 38.

Muhammad, R. (2008). Akuntansi Keuangan Syariah. Yogyakarta: P3EI Press. Muhammad. (2014). Manajemen Dana Bank Syariah. Jakarta: PT Raja Grafindo Persada. 
Mukhlis, \& Suardi, D. (2020). Pengantar Ekonomi Islam. Surabaya: CV. Jakad Media Publishing.

Mutia, E., Jannah, R., \& Rahmawaty. (2018). Islamicity Performance Index of Islamic Banking in Indonesia. Atlantis Press, 424 - 436.

Nasrudin, J. (2019). Metodologi Penelitian Pendidikan: Buku Ajar Praktis Cara Membuat Penelitian. Bandung: Panca Terra Firma Publishing.

Nur, M. S., \& Uyun, A. S. (2020). TINJAUAN PUSTAKA SISTEMATIS: Pengantar metode penelitian sekunder untuk energi terbarukan - bioenergi. Klaten: Lakeisha.

Nurdin, I., \& Hartati, S. (2019). Metodologi Penelitian Sosial. Surabaya: Media Sahabat Cendekia.

Nursam, N. (2017). Manajemen Kinerja . Kelola: Journal of Islamic Education Management.

OJK. (2014). POJK Nomor 8/POJK.03/2014 tentang Penilaian Tingkat Kesehatan Bank Umum Syariah dan Unit Usaha Syariah. Jakarta: Otoritas Jasa Keuangan.

OJK. (2020, Maret). Retrieved from Snapshot Otoritas Jasa Keuangan: https://www.ojk.go.id/id/kanal/syariah/berita-dankegiatan/publikasi/Pages/Snapshot-Perbankan-Syariah-Juni-2020.aspx

OJK. (2020). Laporan Publikasi Tahunan Bank Syariah. Retrieved from https://www.ojk.go.id/id/kanal/perbankan/data-dan-statistik/laporankeuangan-perbankan/default.aspx

OJK. (2020). Retrieved from Laporan Publikasi Bank Umum Syariah: https://www.ojk.go.id/id/kanal/perbankan/data-dan-statistik/laporankeuangan-perbankan/default.aspx

OJK. (2020). Snapshot Perbankan Syariah di Indonesia. Jakarta: OJK.

OJK. (2020). Statistik Perbankan Indonesia. Volume 18 No.8, 29 - 36.

P., I. I., \& Cahyaningrum, I. (2019). Cara Mudah Memahami Metodologi Penelitian. Yogyakarta: DEEPUBLISH CV. Budi Utama.

Permatasari, D. (2018). Analisis Kinerja Keuangan: Kemampuan Bank Syariah dalam Penyaluran Pembiayaan. Jurnal Akuntansi Indonesia, Vol.7, No.1. 
Prasetyo, A. (2014). Kepemimpinan dalam Perspektif Islam. Sidoarjo: Zifatama Jawara.

Prihadi, T. (2019). Analisis Laporan Keuangan. Jakarta: Gramedia Pustaka Utama. Purwoko, D., \& Sudiyatno, B. (2013). Faktor - Faktor yang Mempengaruhi Kinerja Bank (Studi Empirik Pada Industri Perbankan di Bursa Efek Indonesia). JBE: Jurnal Bisnis dan Ekonomi, Vol.20, No.1.

Putri, I. F., Puspitosari, I., \& Wijayanti, F. L. (2019). The Islamicit of Sharia Rural Banks in Indonesia. Muqtasid, Vol.10,No.2, 124 - 138.

Rahadi, D. R. (2010). Manejemen Kinerja Sumber Daya Manusia. Malang: Tunggal Mandiri Publishing.

Raja Ria Yusnita. (2019). Analisis Kinerja Bank Umum Syariah dengan Menggunakan Pendekatan Islamicity Performance Indes Periode tahun 2012 - 2016. Jurnal Tabarru': Islamic Banking and Finance, 15.

Rangkuti, A. A. (2017). Statistika Inferensial untuk Psikologi dan Pendidikan. Jakarta: Kencana.

Rismawati, \& Mattalata. (2018). Evaluasi Kinerja: Penilaian Kinerja Atas Dasar Prestasi Kerja Berorientasi Kedepan . Makassar: Celebes Media Perkasa.

Riswan, \& Kesuma, Y. F. (2014). Analisis Laporan Keuangan Sebagai Dasar dalam Penilaian Kinerja Keuangan PT. Budi Satria Wahana Motor. Jurnal Akuntansi \& Keuangan, Vol.5, No.1.

Runtuwene, A., Pelleng, F. A., \& Manoppo, W. S. (2019). Analiss Rasio Solvabilitas Untuk Mengukur Kinerja Keuangan Pada Bank SulutGo. JAB: Jurnal Administrasi Bisnis, Vol.9, No.2.

Sa'diyah, M., \& Arifin, M. A. (2013). Mudharabah dalam Fiqh dan Perbankan Syariah . Equilibrium, Vol.1 No.2, 310 - 312.

Sa'diyah, M., \& Aziroh, N. (2014). Musyarakah dalam Fiqih dan Perbankan Syariah. Equilibrium, Vol.2, No.2, 314.

Sabirin. (2018). Analisa Kinerja Perbankan Syariah di Indonesia dengan Menggunakan Pendekatan Islamicity Performance Index dan Islamic Corporate Governance. Al - Maslahah, Vol.14 No.2.

Sanjaya, S., \& Rizky, M. F. (2018). Analisis Profitabilitas dalam Menilai Kinerja Keuangan Pada PT. Taspen (Persero) Medan. KITABAH, Vol.2, No.2. 
Sari, E. K. (2007). Pengantar Hukum Zakat dan Wakaf. Jakarta: PT Grasindo.

Sarwat, A. (2019). Ensiklopedia Fikih Indonesia 4: Zakat. Jakarta : PT Gramedia Pustaka Utama.

Sebtianita, E. (2015). Analisis Kinerja Bank Umum Syariah dengan Menggunakan Pendekatan Islamicity Peformance Index (Studi pada Bank Umum Syariah Periode Tahun 2009 - 2013). El-Dinar Vol.3 No.1, 109 - 110.

Seran, S. (2020). Metodologi Penelitian Ekonomi dan Sosial. Yogyakarta: Deeplublish.

Shofaussamawati. (2014). Dakwah Al-Quran terhadap Semangat Etos Kerja . Jurnal An-Nida: Jurnal Komunikasi Islam, Vol.6, No.2.

Sinaga, O. S., \& dkk. (2020). Manajemen Kinerja dalam Organisasi. Medan: Yayasan Kita Menulis.

Sipatutar, M. A. (2007). Persoalan - Persoalan Perbankan Indonesia. Jakarta: Gorga Media.

Siregar, A. Z., \& Harahap, N. (2019). Strategi dan Teknik Penulisan Karya Tulis Ilmiah dan Publikasi. Yogyakarta: CV. Budi Utama .

Sjahdeini, S. R. (2018). Perbankan Syariah: Produk - Produk dan Aspek - Aspek Hukummnya. Jakarta: Kencana.

Sobirin, A. (2014). Konsep Dasar Kinerja dan Manajemen Kinerja. Jakarta: Universitas Terbuka.

Soegoto, E. S. (2011). Penerapan Manajemen Kinerja dengan Pendekatan Balance Scorecard Dalam Meningkatkan Akuntabilitas Pengelolaan Penguruan Tinggi. Majalah Ilmiah UNIKOM, Vol.6, No.2.

Subardi, H. P. (2019). Kebutuhan AAOIFI Sebagai Standar Akuntansi Keuangan Syariah dalam Harmonisasi Penyajian Laporan Keuangan. Jurnal OWNER: Riset dan Jurnal akuntasi.

Sugiono, A. (2009). Manajemen Keuangan untuk Praktisi Keuangan. Jakarta: PT. Gramedia Widiasarana Indonesia.

Sulaksono, H. (2015). Budaya Organisasi dan Kinerja. Surabaya: Deepublish. Sundari, S. (2019). Manajemen Kinerja. Bogor: Universitas Pertahanan. 
Supriyaningsih, O. (2020). Analisis Kinerja Perbankan Syariah di Indonesia dengan menggunakan pendekatakan Islamicity Indeces. REVENUE: Jurnal Manajemen Bisnis Islam Vol.1 No.1, 48 - 49.

Suryani, N. K., \& FoEh, J. E. (2018). Kinerja Organisasi. Yogyakarta: CV Budi Utama.

Tersiana, A. (2018). Metode Penelitian. Sidoarjo: Anak Hebat Indonesia.

Tohardi, A. (2019). Pengantar Metodologi Penelitian Sosial. Pontianak: Tanjungpura University Press.

Trisiolo, R. B. (2020). Pengaruh Zakat terhadap Kinerja Bank Umum Syariah di Indonesia Periode 2013-2018. Karya Ilmiah Universitas Trilogi Jakarta.

Tunggul, A. M., Isnanto, R., \& Nurhayati, O. D. (2016). Evaluasi Kinerja Organisasi Publik dengan Menggunakan Pendekatan Balanced Scorecard dan Analytic Network Process. Jurnal Sistem Informasi Bisnis, Vol.2.

Ulfa, M., \& Ridwan, M. (2015). Analisis Pengukuran Kinerja Karyawan dengan Metode Human Resources Scorecard di BMT Logam Mulia. EQUILIBRIUM: Jurnal Ekonomi Syariah, Vol.3, No.2.

Unaradjan, D. D. (2019). Metode Penelitian Kuantitatif. Jakarta: Univesitas Katolik Indonesia Atma Jaya.

Wahyuni, S. (2020). Perbankan Syariah: Pendekatan Penilaian Kinerja. Pasuruan: Qiara Media.

Wahyuni, Sri. (2020). Kinerja Maqashid Syariah dan Faktor - Faktor Determinan. Surabaya: Scopindo Media Pustaka.

Wangsawidjaja. (2012). Pembiayaan Bank Syariah. Jakarta: PT Gramedia Pustaka Utama.

Widyastuti, E. D., \& Waridin. (2002). Pengaruh Imbalan, Kondisi Fisik Lingkungan dan Hubungan antar Karyawan Terhadap Prestasi Kerja Tenaga Medis. Ekobis, Vol.17 No.2, 121.

Widyatuti, M. (2017). Analisa Kritis Laporan Keuangan. Surabaya: CV. Jakad Media Nusantara.

Wijayanti, A., \& Wimbarti, S. (2012). Evaluasi dan Pengembangan Sistem Penilaian Kinerja pada PT HKS. Jurnal Psikologi Undip, Vol.11, No.2. 
Yermia Egam, G. E. (2017). Pengaruh Return on Asset (ROA), Return on Equity (ROE), Net Profit Margin (NPM), dan Earning Per Share (EPS) terhadap Harga Saham Perusahaan yang tergabung dalam Indeks LQ45 di Bursa Efek Indonesia (BEI) periode tahun 2013 - 2015. Jurnal EMBA, Vol.5, No.1, 108.

Yulianto, N. B., Maskan, M., \& Utaminingsih, A. (2018). Metodologi Penelitian Bisnis. Malang: Polinema Press.

Yuniarti, R., \& dkk. (2018). Green Supply Chain Management dan Studi Kasus di Dunia Industri. Malang: UB Press.

Yusnita, R. R. (2019). Analisis Kinerja Bank Umum Syariah dengan Menggunaka Pendekatan Islamicity Performance Index Periode tahun 2012 - 2016. Jurnal Tabarru': Islamic Banking and Finance Vol.2 No.1 , 13.

Zainudin, M. (2020). Metodologi Penelitian Kefarmasian dan Kesehatan Edisi 2. Surabaya: Airlangga University Press. 